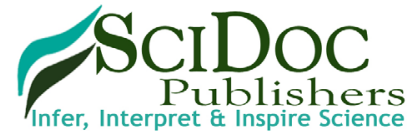

International Journal of Food Science, Nutrition and Dietetics (IJFS)

ISSN:2326-3350

\title{
Prevalence of Malnutrition and Monitoring of Food Consumption among Hospitalized Patients
}

\author{
Research Article
}

Radha Reddy Chada ${ }^{1 *}$, Bhagyasri A Goud², Rajiv Medanki³, Anita Maska², Balakrishna Nagalla ${ }^{4}$

${ }^{1}$ Head, General Manager, (Nutrition), Department of Clinical Nutrition and Dietetics, Sunshine Hospitals, Secunderabad, Telangana, India.

${ }^{2}$ Senior Dietitian, Department of Clinical Nutrition and Dietetics, Sunshine Hospitals, Secunderabad, Telangana, India.

${ }^{3}$ Consultant Nephrologist, Department of Nephrology, Sunshine Hospitals, Secunderabad, Telangana, India.

${ }^{4}$ Scientist E (Retired), Division of Biostatistics, National Institute of Nutrition, Hyderabad, Telangana, India.

\section{Abstract}

Under-nourishment of hospitalized patients has been a problem recognized for nearly 40 years. It is associated with increased risk of hospital-acquired infections, delayed wound healing, increased length of stay (LOS), and treatment cost, with higher morbidity and mortality. The problem of iatrogenic malnutrition worsens with existing poor nutritional status. The aim of the study is to identify malnutrition and the determinants of poor dietary intake among hospitalized patients.

Prospective observational study of patients admitted to a tertiary-care hospital. All patients admitted to the hospital wards were screened and assessed with validated tools. Food consumption of $25 \%$ of the patients admitted was assessed. Visual estimation of leftover food in the plate after consumption was performed. Anthropometric data, LOS, and mean intake of energy and protein against delivered quantities were assessed.

1250 patients-538 females and 712 males (mean age $54.98 \pm 15.61$ years) were assessed. The mean BMI of the study group was $25.6 \pm 5.9 \mathrm{~kg} / \mathrm{m}^{2}$. Of these, $45.7 \%$ and $1.2 \%$ were moderately and severely malnourished, respectively. $53.1 \%$ of the patients were well nourished at admission. The mean delivered calorie and protein content of the meal was $568 \pm 104.8 \mathrm{kcal}$ and $21.7 \pm 4.3 \mathrm{gm}$, respectively. The mean consumed energy and protein contentwas $324.4 \pm 224.0)(57 \%)$ and $(12.3 \pm 8.64)$ $(55.3 \%)$ respectively. There was a significant difference in consumption of energy $(p<0.001)$ and protein $(p<0.001)$ among the well-nourished as compared to malnourished patients.

Maintaining good nutritional status is vital. Estimation of plate wastage will facilitate early recognition of poor food intake. Early recognition would help to optimize nutritional intervention.

Keywords: LOS; PGSGA Tool; Energy; Protein; Plate Wastage.

\section{Introduction}

Under-nourishment of hospitalized patients has been a problem recognized for nearly 40 years [1] with disease-specific malnutrition being very significant [2]. Many patients are undernourished at admission or at an increasing risk of malnutrition during hospital stay [3]. Although measurement of malnutrition and methods of nutritional assessment varied, its prevalence in hospitals was reported as 20 to $50 \%$ [4, 5-8]. There are many reasons to explain this. The underlying disease may directly impair nutritional status, which increases the nutritional needs or results in decreased food intake. The problem of iatrogenic malnutrition adds to the existing poor nutritional status at admission.

Those at highest risk for under-nutrition are the elderly, who are hospitalized or living in care homes, on low incomes and/or who are socially isolated, with chronic disorders, and those recovering from a serious illness, which particularly affects their ability to eat [9].

One of the many factors implicated in the etiology of malnutrition is sub-optimal food intake during hospitalization [9-11]. Dur-

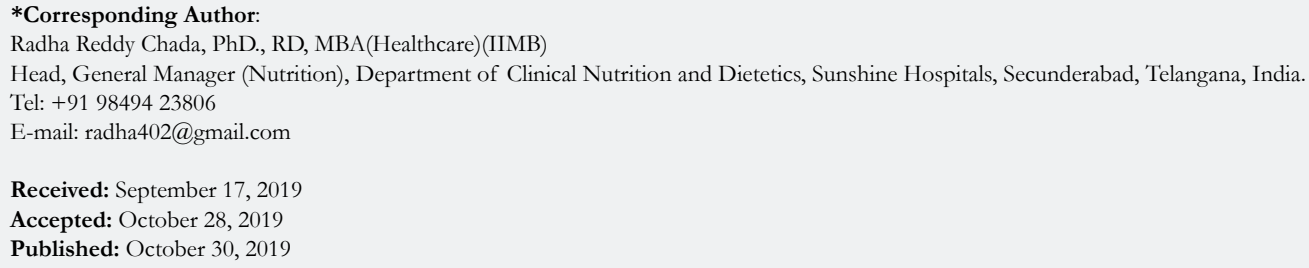

Citation: Radha Reddy Chada, Bhagyasri A Goud, Rajiv Medanki, Anita Maska, Balakrishna Nagalla. Prevalence of Malnutrition and Monitoring of Food Consumption among Hospitalized Patients. Int J Food Sci Nutr Diet. 2019;8(4):412-418. doi: http:/ /dx.doi.org/10.19070/2326-3350-1900074

Copyright: Radha Reddy Chada ${ }^{\circ}$ 2019. This is an open-access article distributed under the terms of the Creative Commons Attribution License, which permits unrestricted use, distribution and reproduction in any medium, provided the original author and source are credited. 
ing hospitalization, patients are often subject to practices that further worsen their nutrition status (eg, traditional preparation for surgery, missed mealtimes for medical procedures, and nil per os orders) [12]. Hospital under-nutrition can also become aggravated because of inappropriate meal services, poor quality and inflexibility of hospital catering services, and insufficient aid provided by care staff $[9,13]$. High food wastage is associated with reduced energy and protein intake and has a bearing on malnutrition-related complications [13]. Whatever the cause of malnutrition, it is associated with increased risk of hospital infections, accelerated muscle loss, delayed wound healing, increased length of stay (LOS) and cost of treatment, and higher morbidity and mortality risk [14-18]. According to Nutrition Day results, patients on nil per oral orders or those who skip their meal are at higher risk for mortality during hospital stay [11]. One large survey showed that four out of five patients do not consume enough to meet their energy and/or protein needs [9]. On an average, nearly $50 \%$ of patients reported eating half or less of their meal, and these patients were found to be up to four times more likely to be malnourished compared to those who ate more than half of their meal [19]. Therefore, assessment of nutritional status at admission for the early detection of malnutrition among patients and monitoring nutritional intake to identify those whose nutritional needs are not met by hospital food is very important [20]. Inspection of the meals tray and the estimation of the unconsumed food on it is a very important parameter to evaluate nutritional intake of patients during hospitalization. It has also been proposed by the Nutrition Day project that day-to-day food consumption be monitored for the estimation of food consumed by the patients [21].

The prevalence of malnutrition among hospitalized patients is not well studied in this country. This makes planning of nutritional therapy for patients with malnutrition difficult. This Prospective Observational study was conducted with the following objectives:

- To determine the prevalence of malnutrition at admission.

- To evaluate patients' food consumption during hospital stay.

- Evaluate the differences in food intake of well-nourished and malnourished patients in hospital.

- To identify the reasons for poor consumption of food and provide suggestions for improvement.

\section{Meterials and Methods}

Prospective observational study of patients admitted during a period of one month, in a tertiary-care hospital. Patients admitted and hospitalized more than 24 hours from 01 September to 01 October 2018 were included in the study.

The study was approved by Institutional Ethical Committee. Informed consent was obtained from all subjects (ethics approval number: SS/2018/IEC 277). Patients on nil per oral (NPO), criticallyill patients, pregnant women, those below 18 years of age, day care patients, and patients on artificial nutritional support, were excluded from the study.

\section{Nutritional Screening and Assessment for Malnutrition}

To evaluate nutritional status, each participant was initially screened at admission by MST (malnutrition screening tool). All patients were assessed as per hospital protocol by Subjec- tive Global Assessment (SGA) and Patient Generated Subjective Global Assessment (PGSGA) tool. Based on the World Health Organization's International Statistical Classification of Diseases and Related Health Problems (ICD-10) [22], malnutrition was defined as $\mathrm{BMI}<18.5 \mathrm{~kg} / \mathrm{m}^{2}$, and as per SGA rating as moderately malnourished (SGA -B) or severely malnourished (SGA-C). Over a 24 -hr period, $25 \%$ of the participants' food intake was observed and recorded on a six-point scale.

Anthropometric and biochemical parameters were assessed. Dietary intake during hospital stay was evaluated by monitoring plate wastage. Based on PGSGA/SGA scores, the subjects were categorized into three groups: A-well nourished, B-Moderately malnourished and C-Severely malnourished. Length of hospital stay [LOS], mean \pm SD of energy and protein adequacy between the groups was calculated. The overall adequacy of energy and protein intake was estimated using individualized dietary recommendations.

\section{Assessment of food intake by Plate Wastage Method}

During the survey period, $25 \%(n=302)$ of the patients were assessed for plate wastage during hospital stay. Plate wastage refers to the volume or percentage of the served food that is discarded [24]. At the end of the meal, dieticians visually evaluated the proportion of food on the plate consumed by each subject on a Comstock6-point scale (all, $3 / 4,1 / 2,1 / 4,<1 / 4$, and none) [23]. Proportion of food on plate left unconsumed by the participants, along with the reasons for not consuming the food, were recorded.

The energy and protein content of each meal served to the patients was calculated. Patients on both normal and therapeutic diets were considered. The nutritive values of food served, consumed and wasted during one meal (lunch) on one day was estimated. A structured interview was recorded to evaluate the reasons for non-consumption of food and elucidate the relationship between food intake and disease and the meal quality.

\section{Statistical Methodology}

SPSS Windows version 24.0 was used for statistical analysis. Mean and SD values were calculated for quantitative and normality characteristics variables, median and IQR were calculated for non-normal variables. Percentages were calculated for qualitative variables. Mean values of BMI, LOS, energy and protein intakes were compared by PGSGA/SGA using one-way ANOVA/Kruskal Wallis one-way with post hoc test of LSD was performed. Chi-square test was performed to study the association of BMI grades with PGSGA. Risk estimate was calculated by odds ratio with $95 \%$ Confidence Interval. Level of significance was considered as 0.05 .

\section{Results and Discussions}

A total of 1250 in-patients were admitted in the study, between the ages of $18-96$ years (mean age $54.9 \pm 15.7$ ). The study population consisted of 538 females and 712 males, with a mean BMI of $25.6 \pm 5.9 \mathrm{~kg} / \mathrm{m}^{2}$ as shown in Table 1 .

In this study, the subjects were drawn from 13 medical departments of the hospital, with different medical profiles as shown in Figure 1. 
Table 1. Characteristics of Study Population.

\begin{tabular}{|c|c|c|c|}
\hline Character & Male & Female & Total \\
\hline Number $(\%)$ & $712(57 \%)$ & $538(43 \%)$ & $1250(100 \%)$ \\
\hline Age (years) & $55.3 \pm 15.1$ & $54.7 \pm 16.0$ & $54.9 \pm 15.7$ \\
\hline BMI $\left(\mathrm{kg} / \mathrm{m}^{2}\right)$ & $24.9 \pm 5.5$ & $26.4 \pm 6.2$ & $25.6 \pm 5.9$ \\
\hline Length of stay (LOS) (days) & $4.3 \pm 3.35$ & $4.1 \pm 2.99$ & $4.19 \pm 3.2$ \\
\hline \multicolumn{4}{|c|}{ Dietary type } \\
\hline Vegetarian (Num) (\%) & $107(15 \%)$ & $85(16 \%)$ & $192(15 \%)$ \\
\hline Non-vegetarian (Num) (\%) & $605(85 \%)$ & $453(84 \%)$ & $1058(85 \%)$ \\
\hline
\end{tabular}

Figure 1. Number of Patients from Different Departments of Hospital.

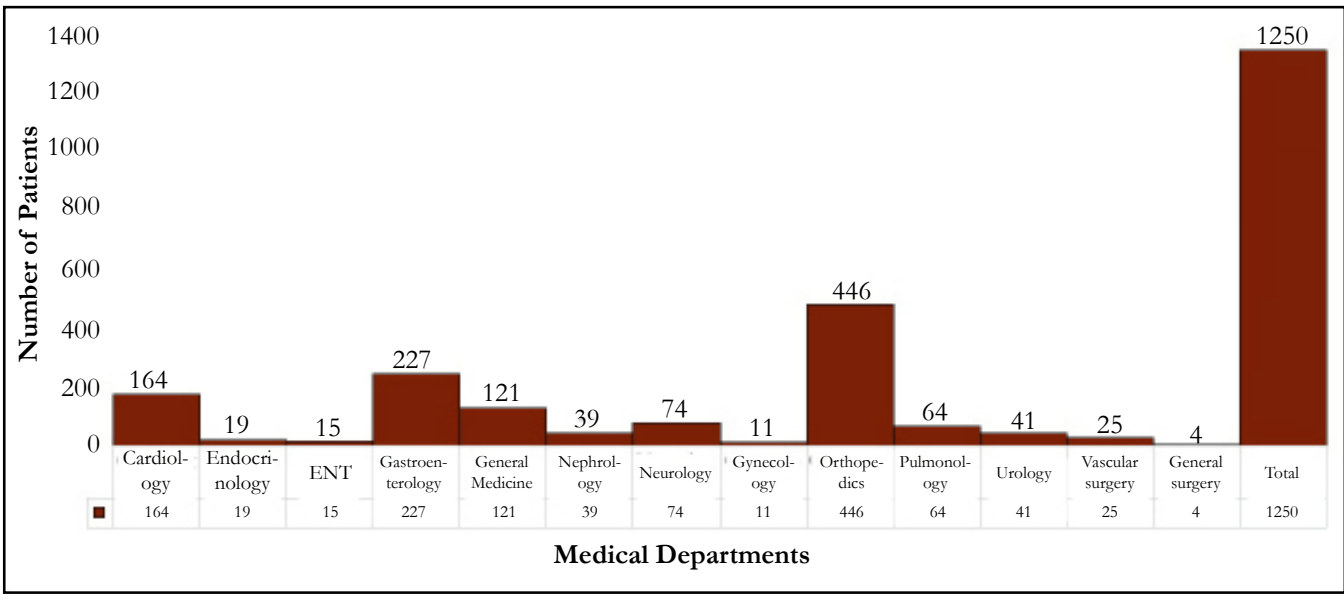

\section{Prevalence of Malnutrition}

The nutritional status of 1250 subjects was assessed by two different tools - SGA and PGSGA, and showed similar results. Among those patients assessed by PGSGA, $53.1 \%(n=664)$ were wellnourished [grade $\mathrm{A}$ ], 45.7\% ( $\mathrm{n}=571)$ were moderately malnourished and $1.2 \%(\mathrm{n}=15)$ were severely malnourished at admission, similar to the results assessed by SGA as shown in Table 2. Of the 571 moderately malnourished patients, there were 53 of them who were underweight i.e. $<18.5 \mathrm{~kg} / \mathrm{m}^{2} \mathrm{BMI}$, and 4 out of the 15 severely malnourished individuals were $<18.5 \mathrm{~kg} / \mathrm{m}^{2}$ BMI. Similar trend has been observed among the patients assessed by SGA as shown in Table 2.

When mean BMI is categorised by PGSGA/SGA, it is observed that mean $B M I$ significantly $(\mathrm{p}<0.001)$ decreases from grade ' $\mathrm{A}$ ' $(26.3 \pm 5.6)$ to grade ' $C$ ' $(19.5 \pm 3.97)$ as shown in Table 2.

The length of stay (LOS) significantly increased from $3.75 \pm 2.6$ to $7.13 \pm 8.1$ days, with significant $(\mathrm{p}<0.001)$ decrease in nutritional status as assessed by both PGSGA and SGA, Table $2(\mathrm{p}<0.001)$.

The prevalence of malnutrition according to PGSGA \& SGA varied between different age groups. The elderly (aged $\geq 60$ years) had a significantly higher prevalence of moderate malnutrition, ranging from $47 \%$ to $80 \%$, than the younger age group (30-59 years) ranging from $28 \%$ to $44 \%(\mathrm{p}<0.001)$.

According to the BMI classification, the study population showed significant difference in the prevalence of malnutrition among the different medical departments. The prevalence of undernutrition
$\left(\mathrm{BMI}<18.5 \mathrm{~kg} / \mathrm{m}^{2}\right)$ was $13 \%$ each in the patients admitted under gastroenterology and neurology departments.

$71 \%(n=116)$ of cardiology patients and $79 \%(n=352)$ in orthopaedics were overweight or obese $(B M I \geq 23)$ and were classified as well-nourished according to PGSGA/SGA.

\section{Food Intake}

Food intake was monitored in 302 patients. There were $43 \%$ $(n=131)$ females and $57 \%(n=171)$ males whose meal consumption was monitored. Of these, $35 \%(\mathrm{n}=106)$ were in twin sharing rooms, $22 \%(n=68)$ in single rooms, $22 \%(n=68)$ in general ward, and $20 \%(n=60)$ in triple-sharing accommodation.

Of the 302 patients, $35 \%(n=106)$ consumed all the food, $13 \%$ $(n=39)$ did not eat at all, and $23 \%(n=68)$ consumed $50 \%$ of food served, as shown in Table 3. The food consumed was categorised as $>50 \%$ and $\leq 50 \%$ of food intake. There were $44 \%(n=134)$ patients whose intake was $>50 \%$ of the meal and $56 \%(n=168)$ patients consumed $\leq 50 \%$ of the meal among the study population.

On an average, one in every 4 patients were malnourished (SGA $\mathrm{B}$ and C) among those who ate $\leq 50 \%$ of the food offered ( $\mathrm{n}=83$, $28 \%$ ). In contrast, 1 in $5(n=60)$ of the study population were malnourished among those who ate $>50 \%$ of food.

It is observed that the mean energy and protein of $>50 \%$ meal consumed among the well-nourished and moderately malnourished patients is roughly equal. Similarly, the median with IQR values of energy $(570,454,620 \mathrm{kcal})$ and protein $(20,18,24 \mathrm{gms})$ 
Table 2. Nutritional Status Indicators and LOS.

\begin{tabular}{|c|c|c|c|c|c|c|}
\hline \multirow{2}{*}{\multicolumn{2}{|c|}{$\begin{array}{c}\text { Nutritional status } \\
\text { grade PGSGA } \\
\text { No. of patients }(\%)\end{array}$}} & \multicolumn{3}{|c|}{$\begin{array}{c}\text { BMI categories } \mathrm{kg} / \mathrm{m}^{2} \\
\text { No. of patients }(\%)\end{array}$} & \multirow{3}{*}{$\begin{array}{c}\text { BMI with } \\
\text { PGSGA/SGA } \\
\text { Mean } \pm \text { SD }\end{array}$} & \multirow{3}{*}{$\begin{array}{c}\text { LOS according } \\
\text { to } \begin{array}{c}\text { PGSGA/SGA } \\
\text { Mean } \pm \text { SD }\end{array} \\
3.75 \pm 2.6\end{array}$} \\
\hline & & \multirow{2}{*}{$\begin{array}{l}<18.5 \\
19(3)\end{array}$} & \multirow{2}{*}{$\frac{18.5-23}{128(19)}$} & \multirow{2}{*}{$\frac{\geq 23}{517(78)}$} & & \\
\hline Grade A & $664(53.1)$ & & & & & \\
\hline Grade B & $571(45.7)$ & $53(9)$ & $166(29)$ & $352(62)$ & $24.8 \pm 6.1$ & $4.63 \pm 3.5$ \\
\hline Grade C & $15(1.2)$ & $4(27)$ & $6(40)$ & $5(33)$ & $20.33 \pm 3.9$ & $7.13 \pm 8.1$ \\
\hline p value & & & & & $<0.001$ & $<0.001$ \\
\hline \multicolumn{7}{|c|}{$\begin{array}{l}\text { Nutritional status } \\
\text { grade SGA } \\
\text { No. of patients }(\%)\end{array}$} \\
\hline Grade A & $653(52)$ & $21(3)$ & $131(20)$ & $501(77)$ & $26.4 \pm 5.7$ & $3.85 \pm 2.95$ \\
\hline Grade B & $585(47)$ & $51(9)$ & $164(28)$ & $370(63)$ & $24.8 \pm 5.98$ & $4.52 \pm 3.4$ \\
\hline Grade C & $12(1)$ & $4(33)$ & $5(42)$ & $3(25)$ & $19.5 \pm 3.97$ & $6.75 \pm 2.9$ \\
\hline p value & & & & & $<0.001$ & $<0.001$ \\
\hline
\end{tabular}

Table 3. Food Intake.

\begin{tabular}{|c|c|c|}
\hline Food Consumed & Number of patients (\%) & Categorisation \\
\hline Full portion remains & $39(13)$ & \multirow{4}{*}{$\leq 50 \%$ of food intake } \\
\hline $1 / 4$ eaten & $23(8)$ & \\
\hline less than $1 / 4$ eaten & $38(12)$ & \\
\hline $1 / 2$ of portion remains & $68(23)$ & \\
\hline $1 / 4$ of portion remains & $28(9)$ & \multirow{2}{*}{$>50 \%$ of food intake } \\
\hline Full portion eaten & $106(35)$ & \\
\hline
\end{tabular}

between the well-nourished and moderately malnourished groups is similar. In contrast, among the patients who consumed $>50 \%$ of meal, when categorized according to BMI, the mean energy and protein significantly increased with increase in BMI, Table 4. An increasing trend of median energy (520-570 kcals) and protein (17-20 gms) with increasing BMI was observed.

Likewise, the mean energy and protein of the all patients who consumed $\leq 50 \%$ of meal was similar across different grades of nutritional status. The median values of energy $\left(138 \mathrm{kcal} ; 25^{\text {th }}, 75^{\text {th }}\right.$ percentile) and protein ( $5.0 \mathrm{gms} ; 25^{\text {th }}, 75^{\text {th }}$ percentile) between the well-nourished and moderately malnourished groups was roughly equal. Among patients who consumed $\leq 50 \%$ of meal, when categorized according to BMI, the mean energy and protein of the meal consumed decreased with increase in BMI, Table 4. Similar decreasing trend of median energy $\left(275-138 \mathrm{kcals} ; 25^{\text {th }}, 75^{\text {th }}\right.$ percentile) and protein (10-4.5 gms; $25^{\text {th }}, 75^{\text {th }}$ percentile) intake with increasing BMI was observed.

\section{Reasons for Food Wastage}

Although 97\% ( $n=292)$ patients rated the temperature as just right, and 90\% ( $\mathrm{n}=271)$ patients felt the portion size was appropriate and $92 \%(n=278)$ patients rated the texture and flavor as good, only $35 \%(n=106)$ consumed the entire meal. This suggests there are other reasons for plate wastage and poor consumption of food.

There are many reasons for plate wastage in hospitals - some related to patient's condition and some to the food service system.
These reasons are broadly categorized under four sections [24], namely clinical, food service issues, environmental issues, and no reasons, as shown in Table 5.

Of the 50 patients who had food and menu issues, it was observed that $23 \%(n=31)$ were moderately malnourished. Similarly, of the 142 patients who had clinical reasons for plate wastage, $43 \%(n=59)$ were moderately malnourished and 3.5\% (n=5) severely malnourished.

The recognition of malnutrition and early nutritional therapy in hospitalized patients is important along with the treatment of underlying diseases. However, malnutrition among hospitalized patients is overlooked, $[4,5,7]$ either because medical resources, such as the availability of nutrition specialists, or hospital and financial support, are inadequate, or because clinicians do not recognize malnutrition to be a vital issue [11].

Our study is a snapshot of the association between malnutrition, poor food intake and patient outcomes in this region.

With almost half of all participants malnourished, the results are comparable to malnutrition prevalence reports from other countries $[6,25]$ and the study by Chakravarthy et al., thereby confirming that malnutrition is an ongoing issue in the acute hospital setting in this region [26]. The ICD-10 definition of malnutrition uses BMI $<18.5 \mathrm{~kg} / \mathrm{m}^{2}$ or presence of at least $5 \%$ weight loss, decreased intake and presence of subcutaneous fat loss and/or muscle wasting, which are components of SGA. The SGA is a valid and reliable tool, has good intra- and inter-rater reliability, 
Table 4. Nutritional Status Indicators and Food Intake.

\begin{tabular}{|c|c|c|c|c|c|c|c|}
\hline \multirow[b]{2}{*}{ S1. No. } & \multirow[b]{2}{*}{$\begin{array}{l}\text { Nutritional } \\
\text { status }\end{array}$} & \multicolumn{3}{|c|}{$>50 \%$ Food Intake } & \multicolumn{3}{|c|}{$\leq 50 \%$ Food Intake } \\
\hline & & $\begin{array}{c}\text { No. of } \\
\text { Patients } \\
(\%)\end{array}$ & $\begin{array}{c}\text { Mean } \\
\text { Energy kcals } \\
\text { consumed }\end{array}$ & $\begin{array}{c}\text { Mean } \\
\text { Proteingms } \\
\text { consumed }\end{array}$ & $\begin{array}{c}\text { No.of } \\
\text { Patients } \\
(\%)\end{array}$ & $\begin{array}{c}\text { Mean Energy } \\
\text { kcals } \\
\text { consumed }\end{array}$ & $\begin{array}{c}\text { Mean } \\
\text { Protein gms } \\
\text { consumed }\end{array}$ \\
\hline 1 & Grade A & $74(25)$ & $542 \pm 110$ & $20.5 \pm 4.6$ & $85(28)$ & $153 \pm 127$ & $5.7 \pm 4.7$ \\
\hline 2 & Grade B & $60(20)$ & $527 \pm 110$ & $20.3 \pm 4.8$ & $78(26)$ & $154 \pm 127$ & $6.0 \pm 4.9$ \\
\hline 3 & Grade C & - & - & - & $5(2)$ & $202 \pm 153$ & $7.0 \pm 5.2$ \\
\hline \multicolumn{3}{|c|}{$\mathrm{p}$ value } & 0.473 & 0.841 & & 0.700 & 0.859 \\
\hline 4 & $\mathrm{BMI}<18.5$ & $5(2)$ & $464 \pm 158$ & $16.4 \pm 6$ & $15(5)$ & $198 \pm 128.8$ & $7.3 \pm 4.6$ \\
\hline 5 & BMI18.5-<23 & $26(9)$ & $499 \pm 132.6$ & $18.8 \pm 5$ & $37(12)$ & $153 \pm 132$ & $5.9 \pm 4.9$ \\
\hline 6 & $\mathrm{BMI} \geq 23$ & $103(34)$ & $548 \pm 99.2$ & $21 \pm 4.4$ & $116(38)$ & $150 \pm 125.3$ & $5.7 \pm 4.8$ \\
\hline \multicolumn{3}{|c|}{$\mathrm{p}$ value } & 0.118 & 0.029 & & 0.293 & 0.458 \\
\hline
\end{tabular}

Table 5. Reasons for Food Wastage.

\begin{tabular}{|c|c|c|c|}
\hline S1.No & $\begin{array}{c}\text { Reasons for } \\
\text { food wastage Categories }\end{array}$ & Reasons for food wastage & $\begin{array}{l}\text { Number of } \\
\text { patients (\%) }\end{array}$ \\
\hline \multirow{6}{*}{1} & \multirow{6}{*}{ Clinical issues } & Poor appetite (illness; medication) & \multirow{6}{*}{$142(47 \%)$} \\
\hline & & Special diets - texture modified diets & \\
\hline & & Changes in sense of taste or smell & \\
\hline & & Dysphagia,i.e., swallowing difficulty & \\
\hline & & $\begin{array}{l}\text { Pain/too sick/stress from treatment. Cognitive problems } \\
\text { (confusion; inability to recognize food) }\end{array}$ & \\
\hline & & Long length of stay & \\
\hline \multirow{4}{*}{2} & \multirow{4}{*}{ Food and menu issues } & Portion sizes too large & \multirow{4}{*}{$50(17 \%)$} \\
\hline & & Food quality (not tasty/too spicy/over or undercooked food & \\
\hline & & $\begin{array}{l}\text { Menu choice (Limited food choice/lack selective menu/ } \\
\text { dislike food choices) }\end{array}$ & \\
\hline & & Food presentation (not hot enough; poor appearance) & \\
\hline \multirow{7}{*}{3} & \multirow{7}{*}{$\begin{array}{c}\text { Service and } \\
\text { Environmental } \\
\text { issues }\end{array}$} & $\begin{array}{l}\text { Physical problems (packaging; food out of reach; immobil- } \\
\text { ity; need for feeding assistance) }\end{array}$ & \multirow{7}{*}{$4(1.3 \%)$} \\
\hline & & Plated food systems & \\
\hline & & Ordering problems (insufficient information) & \\
\hline & & Negative attitude of the food service personnel & \\
\hline & & Incorrect items delivered & \\
\hline & & $\begin{array}{l}\text { Mealtime inappropriate, Ward environment (eg others mov- } \\
\text { ing; noise; smells) }\end{array}$ & \\
\hline & & $\begin{array}{l}\text { Insufficient time to eat (slow eaters) Meal interruptions } \\
\text { (ward rounds; tests) }\end{array}$ & \\
\hline 4 & No reasons & & $106(35 \%)$ \\
\hline
\end{tabular}

is easy to administer, and was therefore selected as the tool of choice for the present study [27].

The study also identified that some participants who might be considered "healthy" based on BMI, were in fact malnourished (SGA-B or SGA-C) when a comprehensive nutritional assessment was performed. Therefore, it is possible for patients with a normal or high BMI to have a sub- optimal nutritional status. In our study, when the mean energy and protein intake significantly fell with decrease in BMI, it indicates that it maybe starvation related malnutrition [28]. Similarly, when the mean energy and protein of the meal consumed decreased with increase in BMI, it can indicate disease related malnutrition [28], as observed in this study, Table 4.

The study reported prevalence of malnutrition in most of the patients, and a subset of patient's food intake was recorded for a 24-h period. The study highlights the independent association of malnutrition and poor food intake during hospitalisation and the LOS. The fact that two-thirds of the participants did not consume all the food offered in hospital during the survey, and "not hungry" was the most frequently cited explanation, are consistent with the results of the European Nutrition Day Survey [11]. Bauer et al., also found that loss of appetite was the most common 
reason for eating less [19]. The study suggests that eating "less" is common in acute care hospital patients and questions the extent to which nutritional requirements of these patients are met, especially at a time when they are unwell and when nutritional support may be warranted. Sub-optimal food intake over an extended period during hospitalisation carries the potential risk of nutritional status deterioration.

Agarwal et al., reported one-in-two among all the patients consumed $\leq 25 \%$ andone-in-three malnourished patients consumed $\leq 50 \%$ of the offered food, one-in-three well-nourished patients also consumed $\leq 50 \%$ of the offered food [29]. In our study, we had one-in-four well-nourished and malnourished patients respectively, who consumed $\leq 50 \%$ of the offered food.

These results call for more consistent monitoring of hospitalised patients' food intake. Perhaps protocols for recording patients' food intake after each meal need to be implemented, like those for medication charts. Considering our results, and those from the European Nutrition Day Survey, perhaps consumption of $\leq 25 \%$ of the offered food should be used as a screening (and rescreening) tool to commence appropriate medical nutrition therapy. The Council of Europe document 30 on prevention of undernutrition in hospitals recommends that this should be part of the quality management system of every hospital, with the formal involvement of administrative, medical, nursing, dietetic and catering staff, taking into account the costs of medical complications and prolonged hospital stays. Supervision of the tray and the evaluation of the food left on it is a very important parameter to evaluate nutritional intake of patients during hospitalization. It has been also proposed that day-to-day food consumption is to be monitored with an on-bed recording system and an easy registration system, like the one used for the evaluation of the proportion of food consumed in the Nutrition Day project 21. Such protocols to monitor and record food intake do not exist in our country.

"Not hungry" or "loss of appetite" was the primary reason for poor food intake in many studies [31-34] that were associated with decreased energy intake. Current literature suggests patients' appetite during hospital admission can be impacted by several factors, including the illness itself [35-37]. This is not unexpected, since illness can often affect appetite and the senses of taste or smell. Reduced activity while in hospital, and drugs causing anorexia, nausea or gastrointestinal symptoms, can also interfere with appetite. Similar factors have been observed in the present study. Findings from this study emphasize the importance of implementing every step of the nutrition care process (nutrition screening and assessment, nutrition support, nutrition monitoring and evaluation of nutrition support) as standardised practice across acute care hospitals in the country.

Despite evidence documenting the ill effects of malnutrition in the hospital, studies suggest it is a common problem that often goes unrecognized and undertreated $[16,38]$. A growing body of evidence suggests that oral nutrition supplements (ONS), which deliver both macronutrients and micronutrients for special medical purposes in addition to normal food, might improve outcomes among hospitalized patients [39]. A variety of benefits have been found for ONS use, including reduced LOS, [40] inpatient cost, $[40,41]$, complication rates, [41, 42] readmission rates [43, 44], and improved lean body mass [45]. This study is conducted as part of an initiative in the hospital called as "SUN Initiative", meaning scaling-up nutrition initiative. Evidence generated from this study has resulted in initiating a feeding protocol of introducing ONS for all the patients who are malnourished, regardless of food intake. According to the ONS feeding protocol, patients are provided with $100-150 \mathrm{ml}$ of ONS (86kcals of energy and $5 \mathrm{gms}$ of protein per $100 \mathrm{ml}$ ) for 2 or 4 or 6 times/day, depending on the quantity of food consumed and their nutritional status.

A combination of systematic protocolised nutrition care process, as detailed in our study, and early institution of supplemental nutrition, may be a low-cost solution to close the nutritional gap in hospital setting, which may translate to better outcomes.

\section{Ethical Approval}

The study was approved by Institutional Ethical Committee. (ethics approval number: SS/2018/IEC 277).

\section{References}

[1]. Butterworth Jr CE. The skeleton in the hospital closet. Nutrition today. 1974 Mar 1; 9(2):4-8.

[2]. Correia MI, Hegazi RA, Diaz-Pizarro Graf JI, Gomez-Morales G, Fuentes Gutiérrez C, Goldin MF, et al. Addressing Disease-Related Malnutrition in Healthcare: A Latin American Perspective. JPEN J Parenter Enteral Nutr. 2016 Mar; 40(3):319-25. doi: 10.1177/0148607115581373 Epub 2015 Apr 16. PubMed PMID: 25883116.

[3]. Green CJ. Existence, causes and consequences of disease-related malnutrition in the hospital and the community, and clinical and financial benefits of nutritional intervention. Clinical Nutrition. 1999; 18(2):3-28.

[4]. Barker LA, Gout BS, Crowe TC. Hospital malnutrition: prevalence, identification and impact on patients and the healthcare system. Int J Environ Res Public Health. 2011 Feb; 8(2):514-27. PubMed PMID:21556200.

[5]. Gout BS, Barker LA, Crowe TC. Malnutrition identification, diagnosis and dietetic referrals: are we doing a good enough job? Nutrition \& Dietetics. 2009 Dec; 66(4):206-11. https://doi.org/10.1111/j.17470080.2009.01372.x

[6]. Norman K, Pichard C, Lochs H, Pirlich M. Prognostic impact of diseaserelated malnutrition. ClinNutr. 2008 Feb; 27(1):5-15. PubMed PMID: 18061312.

[7]. Waitzberg DL, Caiaffa WT, Correia MI. Hospital malnutrition: the Brazilian national survey (IBRANUTRI): a study of 4000 patients. Nutrition. 2001 Jul-Aug; 17(7-8):573-80. PubMed PMID: 11448575.

[8]. Pirlich M, Schütz T, Norman K, Lübke HJ, Bischoff SC, Bolder U, et al. The German hospital malnutrition study. ClinNutr. 2006 Aug; 25(4):563-72. PubMed PMID:16698132.

[9]. Dupertuis YM, Kossovsky MP, Kyle UG, RagusoCA, Genton L, Pichard C. Food intake in 1707 hospitalised patients: a prospective comprehensive hospital survey. ClinNutr. 2003 Apr; 22(2):115-23. PubMed PMID:12706127.

[10]. Lazarus C, Hamlyn J. Prevalence and documentation of malnutrition in hospitals: a case study in a large private hospital setting. Nutr Diet. 2005 Aug; 62(1): 41-47. https://doi.org/10.1111/j.1747-0080.2005.tb00008.x

[11]. Hiesmayr M, Schindler K, Pernicka E, Schuh C, Schoeniger-Hekele A, Bauer $\mathrm{P}$, et al. Decreased food intake is a risk factor for mortality in hospitalised patients: the Nutrition Day Survey 2006. Clin Nutr. 2009 Oct; 28(5):48491. PubMed PMID: 19573957.

[12]. Krumholz HM. Post-hospital syndrome-an acquired, transient condition of generalized risk. N Engl J Med. 2013 Jan; 368(2):100-102. PubMed PMID: 23301730.

[13]. Barton AD, Beigg CL, Macdonald IA, Allison SP. (2000) High food wastage and low nutritional intakes in hospital patients. Clin Nutr. Dec; 19(6): 445449. PubMed PMID:11104596.

[14]. Lim SL, Ong KC, Chan YH, Loke WC, Ferguson M, Daniels L. Malnutrition and its impact on cost of hospitalization, length of stay, readmission and 3-year mortality. Clin Nutr. 2012 Jun; 31(3):345-50. PubMed PMID: 22122869.

[15]. Chima, CS, Barco K, Dewitt ML, Maeda M, Teran JC, Mullen KD. Relationship of nutritional status to length of stay, hospital costs, and discharge status of patients hospitalized in the medicine service. J Am Diet Assoc. 1997 
Sept; 97(9): 975-80. PubMed PMID: 9284874.

[16]. McWhirter JP, Pennington CR. (1994) Incidence and recognition of malnutrition in hospital. BMJ. 1994 Apr 9; 308(6934):945-8. PubMed PMID: 8173401.

[17]. Wu GH, Liu ZH, Wu ZH, Wu ZG. Perioperative artificial nutrition in malnourished gastrointestinal cancer patients. World J Gastroenterol. $2006 \mathrm{Apr}$ 21; 12(15):2441-4. PubMed PMID: 16688841.

[18]. Allard JP, Keller H, Jeejeebhoy KN, Laporte M, Duerksen DR, Gramlich L, et al. Decline in nutritional status is associated with prolonged length of stay in hospitalized patients admitted for 7 days or more: A prospective cohort study. ClinNutr. 2016 Feb; 35(1):144-52. PubMed PMID: 25660316.

[19]. Bauer J, Bannister M, Crowhurst R, Denmeade SL, Horsley P, Mcdonald C, Martineau J, Willer F, Ash S. nutritionDay: An Australian hospital's participation in international benchmarking on malnutrition. Nutrition \& Dietetics. 2011 Jun; 68(2):134-9. https://doi.org/10.1111/j.1747-0080.2011.01513.x

[20]. Kang MC, Kim JH, Ryu SW, Moon JY, Park JH, Park JK, et al. Prevalence of Malnutrition in Hospitalized Patients: a Multicenter Cross-sectional Study. J Korean Med Sci. 2018 Jan 8; 33(2): e10. PMCID:PMC 5729651 doi:10.3346/jkms.2018.33.e10

[21]. Macdonald AS, Teal G, Bamford C, Moynihan PJ. Hospitalfoodie: an interprofessional case study of the redesign of the nutritional management and monitoring system for vulnerable older hospital patients. Qual Prim Care. 2012; 20(3):169-77. PubMed PMID: 22828671.

[22]. World Health Organization. International statistical classification of diseases and related health problems: 10th revision (ICD-10). http://www. Who. Int/classifications/apps/icd/icd. 1992. https://icd.who.int/browse10/2016/ en\#/E40-E46.

[23]. Comstock EM, St Pierre RG, Mackiernan YD. Measuring individual plate waste in school lunches.Visual estimation and children's ratings vs. actual weighing of plate waste. J Am Diet Assoc. 1981 Sept; 79(3):290-6. PubMed PMID: 7264115.

[24]. Williams P, Walton K. Plate waste in hospitals and strategies for change. eSPEN, the European e-Journal of Clinical Nutrition and Metabolism. 2011 Dec 1; 6(6):e235-41. https://doi.org/10.1016/j.ecinm.2011.09.006

[25]. Banks M, Ash S, Bauer J, Gaskill D. Prevalence of malnutrition in adults in Queensland public hospitals and residential aged care facilities. Nutrition \& Dietetics. 2007 Sep; 64(3):172-8. https://doi.org/10.1111/j.17470080.2007.00179.x

[26]. Chakravarty C, Hazarika B, Goswami L, Ramasubban S. Prevalence of malnutrition in a tertiary care hospital in India. Indian J Crit Care Med. 2013 May; 17(3):170-3. PubMed PMID: 24082614.

[27]. Watterson C, Fraser A, Banks M. Evidence based guidelines for nutritional management of malnutrition in adult patients across the continuum of care. Nutr Diet. 2009 Dec; 66(s3):s1-34. https://doi.org/10.1111/j.17470080.2009.01383.x

[28]. Jensen GL, Mirtallo J, Compher C, Dhaliwal R, Forbes A, Grijalba RF, et al. Adult starvation and disease-related malnutrition: a proposal for etiologybased diagnosis in the clinical practice setting from the International Consensus Guideline Committee. JPEN J Parenter Enteral Nutr. 2010 Mar-Apr; 34(2):156-9. PubMed PMID: 20375423.

[29]. Agarwal E, Ferguson M, Banks M, Bauer J, Capra S, Isenring E. Nutritional status and dietary intake of acute care patients: results from the Nutrition Care Day Survey 2010. ClinNutr. 2012 Feb; 31(1):41-7. PubMed PMID: 21862187.

[30]. BeckAM, Balknäs UN, Fürst P, Hasunen K, Jones L, Keller U, et al. Food and nutritional care in hospitals: how to prevent under nutrition-report and guidelines from the Council of EuropeCommittee of Experts on Nutrition Food Safety and Consumer Protection. ClinNutr. 2001 Oct; 20(5):455-60. PubMed PMID: 11534942.

[31]. Mudge AM, Ross LJ, Young AM, Isenring EA, Banks MD. Helping understand nutritional gaps in the elderly (HUNGER): A prospective study of patient factors associated with inadequate nutritional intake in older medical inpatients. ClinNutr. 2011 Jun; 30(3):320-5. PubMed PMID: 21262553.

[32]. HONG W, KIRK D. The analysis of edible plate waste results in 11 hospitals in the UK. Foodservice Research International. 1995 Feb; 8(2):115-23. https://doi.org/10.1111/j.1745-4506.1995.tb00081.x

[33]. McLymont V, Cox S, Stell F. Improving patient meal satisfaction with room service meal delivery. J Nurs Care Qual. 2003 Jan-Mar; 18(1):27-37. PubMed PMID: 12518836

[34]. Stanga Z, Zurfluh Y, Roselli A, Sterchi A, Tanner B, Knecht G. Hospital food: a survey of patients' perceptions. ClinNutr. 2003 Jun; 22(3):241-6. PubMed PMID: 12765662 .

[35]. Amaral TF, Matos LC, Teixeira MA, Tavares MM, Álvares L, Antunes A. Under- nutrition and associated factors among hospitalized patients. ClinNutr. 2010 Oct; 29(5):580-5. PubMed PMID: 20207055.

[36]. Nieuwenhuizen WF, Weenen H, Rigby P, Hetherington MM. Older adults and patients in need of nutritional support: review of current treatment options and factors influencing nutritional intake. ClinNutr. $2010 \mathrm{Apr}$; 29(2):160-9. PubMed PMID: 19828215

[37]. Patel MD, Martin FC. Why don't elderly hospital inpatients eat adequately? J Nutr Health Aging. 2008 Apr; 12(4):227-31. PubMed PMID: 18373030.

[38]. Lyder CH, Preston J, Grady JN, Scinto J, Allman R, Bergstrom N, et al. Quality of care for hospitalized medicare patients at risk for pressure ulcers. Arch Intern Med. 2001 Jun; 161(12):1549-54. PubMed PMID: 11427104

[39]. Philipson TJ, Snider JT, Lakdawalla DN, Stryckman B, Goldman DP. Impact of oral nutritional supplementation on hospital outcomes. Am J Manag Care. 2013 Feb; 19(2):121-8. PubMed PMID: 23448109.

[40]. Somanchi M, Tao X, Mullin GE. The facilitated early enteral and dietary management effectiveness trial in hospitalized patients with malnutrition. JPEN J Parenter Enteral Nutr. 2011 Mar; 35(2):209-16. PubMed PMID: 21378250.

[41]. Lawson RM, Doshi MK, Barton JR, Cobden I. The effect of unselected post-operative nutritional supplementation on nutritional status and clinical outcome of orthopaedic patients. ClinNutr. 2003 Feb; 22(1): 39-46. PubMed PMID: 12553948.

[42]. Beattie AH, Prach AT, Baxter JP, Pennington CR. A randomised controlled trial evaluating the use of enteral nutritional supplements post-operatively in malnourished surgical patients. Gut. 2000 Jun; 46(6):813-18. PubMed PMID: 10807893.

[43]. Gariballa S, Forster S, Walters S, Powers H. A randomized, double- blind, placebo-controlled trial of nutritional supplementation during acute illness. Am J Med. 2006 Aug; 119(8):693-99. PubMed PMID: 16887416.

[44]. Norman K, Kirchner H, Freudenreich M, Ockenga J, Lochs H, Pirlich M. Three-month intervention with protein and energy rich supplements improve muscle function and quality of life in malnourished patients with nonneoplastic gastrointestinal disease-a randomized controlled trial. ClinNutr. 2008 Feb; 27(1):48-56. PubMed PMID: 17964008.

[45]. Jensen MB, Hessov I. Dietary supplementation at home improves the regain of lean body mass after surgery. Nutrition. 1997 May; 13(5):422-30. PubMed PMID: 9225334 